\title{
MODEL PEMBELAJARAN PADA PENDIDIKAN NON FORMAL TEAM GAMES TOURNAMENT DENGAN MENGGUNAKAN PERMAINAN MONOPOLI
}

\author{
Abdul Rahmat \\ Universitas Negeri Gorontalo \\ Jl. Sudirman 06 Kota Gorontalo 96128 \\ Email: abdulrahmat@ung.ac.id
}

\begin{abstract}
In the learning activities, the location of teaching hours in the last hour makes this subject less desirable, because the last hour, learners identical with the feeling of boredom, sleepy and not concentrated because it was close to home time. Based on the description of the problem, this research is expected to be able to play the role of the teacher as an innovator of learning. This research uses a qualitative approach to get data and analysis through reflective, participative and observative study. Program development is based on data and information from learners, teachers, and classroom setting naturally through two classroom action research cycles. To improve the learning outcomes of practice, a Team Games Tournament learning model is conducted with two cycles. In the first cycle learners are partially unfamiliar with the TGT learning model, so that action is done by giving explanations to the learners about the principle of cooperative learning that requires teamwork and cohesiveness in one group. In the second cycle, students learn to understand the basic principles of learning TGT, This can be seen from the increase in the activities of learners who originally in the first cycle only $88.81 \%$ to $94.03 \%$. Likewise with the results of practical learning showed a significant increase, from the first cycle of only 77.47 to 83.37 in the second cycle. The conclusions of this study, using monopoly games, learners are more interactive and learning practices that many initially want to run into more fun.
\end{abstract}

Keywords:

Learning Outcomes; Practice, Learning Model

\begin{abstract}
Abstrak
Dalam kegiatan pembelajaran, letak jam mengajar yang berada di jam terakhir menjadikan mata pelajaran ini kurang diminati, karena saat jam terakhir, peserta didik identik dengan rasa bosan, mengantuk dan tidak konsentrasi karena sudah mendekati waktu pulang. Berdasarkan uraian permasalahan tersebut, melalui penelitian ini diharapkan guru mampu memainkan peran sebagai inovator pembelajaran.Penelitian ini menggunakan pendekatan kualitatif untuk mendapatkan data dan analisis melalui kajian reflektif, partisipatif dan observatif. Pengembangan program didasarkan pada data dan informasi dari peserta didik, guru dan setting kelas secara alamiah melalui dua siklus penelitian tindakan kelas.Untuk meningkatkan hasil belajar praktek, dilakukan model pembelajaran Team Games Tournament dengan dua siklus. Pada siklus pertama peserta didik sebagian belum terbiasa dengan model pembelajaran TGT, sehingga dilakukan tindakan dengan memberi penjelasan kepada peserta didik tentang prinsip pembelajaran kooperatif yang membutuhkan kerjasama tim dan kekompakan dalam satu kelompok. Dalam siklus kedua peserta didik mulai memahami prinsip dasar pembelajaran TGT, Hal ini dapat dilihat dari peningkatan aktivitas peserta didik yang semula pada siklus pertama hanya $88,81 \%$ menjadi $94,03 \%$. Begitu juga dengan hasil belajar prakteknya menunjukkan peningkatan yang signifikan, dari siklus pertama yang hanya sebesar 77,47 menjadi 83,37 pada siklus kedua.

Kesimpulan penelitian ini, dengan menggunakan permainan monopoli, peserta didik lebih interaktif dan pembelajaran praktek yang awalnya banyak yang ingin kabur menjadi lebih menyenangkan.
\end{abstract}

Kata Kunci:

Hasil Belajar;, Praktek; Model Pembelajaran

\section{A. PENDAHULUAN}

Adanya kurikulum 2013 membuat tenaga pendidik, khususnya guru semakin pintar, kreatif, inovatif dan variatif dalam menggunakan modelmodel pembelajaran dan pendekatan-pendekatan yang relevan dengan kompetensi yang dimiliki oleh guru tersebut. Hal ini dikarenakan, mereka dituntut harus mampu menyusun sendiri kurikulum yang sesuai dan tepat bagi peserta didiknya, guru dituntut harus mampu merencanakan sendiri materi pelajarannya untuk mencapai kompetensi yang telah ditetapkan. Kondisi ini jelas berbeda dengan kurikulum-kurikulum sebelumnya yang datang dari dan dibuat oleh Pemerintah Pusat, dan guru hanya tinggal menerapkannya, sehingga nyaris tidak memberikan ruang dan tantangan bagi pengembangan ide dan kreativitas dari guru.

Pada proses pembelajaran di kelas biasanya guru memberikan tugas (pemantapan) secara kontinu berupa latihan soal-soal. Pembelajaran 
standar juga telah dilakukan oleh guru, berbagai media pembelajaran yang ada di sekolah telah dimanfaatkan, berbagai bentuk penugasan telah pula diberikan untuk dilaksanakan oleh siswa, baik di dalam maupun di luar kelas, mulai dari tugas mengerjakan variasi soal praktek, mengerjakan LKS, post test dan lain sebagainya. Namun demikian, dalam kemampuan psikomotoriknya siswa cenderung enggan melakukan kegiatan praktikum dan pengamatan. Terkadang minatnya masih kurang. Hal ini dapat dilihat dari perilaku siswa yang sering kabur dan tidak melaksanakan sepenuhnya pada saat dilakukan praktek, ditambah lagi dengan posisi waktu KBM pada jam terakhir.

Kegiatan pembelajaran harus berpusat pada siswa, dan bukan pada guru. Guru tidak lagi harus mendominasi kegiatan pembelajaran dengan metode ceramah sampai berbusa-busa, sementara siswa hanya duduk manis mendengarkan sambil bengong atau bahkan sampai terkantuk-kantuk (Berdasarkan hasil observasi 3 Oktober 2016).

Berdasarkan catatan guru, aktivitas siswa dalam kegiatan praktek kelas masing-masing hanya sebesar 30\% dan 35\% dari 19 siswa yang ada. Sebagian besar dari siswa justru memperlihatkan aktivitas yang tidak relevan dengan pembelajaran, seperti kelihatan bengong dan melamun, kurang bergairah, kurang memperhatikan, bermain-main sendiri, berbicara dengan teman ketika dijelaskan, canggung mendemonstrasikan kegiatan praktek atau berdialog dengan teman waktu praktek berlangsung, dan lain sebagainya. Sementara itu dari hasil observasi, prestasi kegiatan psikomotorik mereka hanya sebesar $45 \%$ yang berhasil mencapai batas KKM (Kriteria Ketuntasan Minimal). Padahal KKM yang ditetapkan 75.

Bertolak dari permasalahan tersebut kemudian dilakukan refleksi dan konsultasi dengan guru sejawat untuk mendiagnosis faktor-faktor yang mungkin menjadi penyebab timbulnya masalah. Dari situ diperoleh beberapa faktor kemungkinan penyebab, diantaranya adalah: (1) Faktor rendahnya hasil belajar praktik siswa; (2) Faktor penyampaian materi dari guru;(3) Faktor daya serap siswa yang masih kurang; dan (4) Faktor kesulitan adaptasi dan kerjasama di antara siswa.
Penelitian tindakan kelas ini dilaksanakan di Sanggar Kegiatan Belajar Kabupaten Gorontalo. Sebagai subjek dalam penelitian ini adalah warga belajar Paket B Tahun Pelajaran 2015/2016 dengan jumlah siswa 19 orang, terdiri dari 6 orang siswa laki-laki dan 13 orang siswa perempuan.

Sumber data dalam penelitian ini terdiri dari beberapa sumber, yakni siswa, guru dan Observer. Adapun teknik pengumpulan data yang digunakan adalah tes kemampuan penalaran membaca soal praktek melalui Lembar Kerja Siswa (LKS), Observasi, Post test di akhir kegiatan praktek dan diskusi. Sedangkan alat pengumpulan data dalam PTK ini meliputi tes kemampuan penalaran soal praktek dalam LKS, observasi, post test.(Sugiyono, 2009).

Analisis data dilakukan sejak data diperoleh dari hasil observasi. Data hasil observasi pelaksanaan pembelajaran dengan model pembelajaran Team Games Tournament (TGT) dianalisis secara deskriptif untuk memberikan gambaran keterlaksanaan pembelajaran praktek Teknik konversi bahan.

Hasil tes digunakan untuk mengetahui peningkatan kemampuan penalaran siswa. Menurut Arikunto (2010), analisis hasil belajar peserta didik dengan menganalisis nilai rata-rata post test, kemudian dikategorikan dalam klasifikasi sangat baik, baik, cukup dan tidak baik, dengan kriteria ketuntasan nilai minimal adalah sebesar 75 .

\section{B. HASIL DAN PEMBAHASAN}

Hasil penelitian diuraikan dalam tahapan yang berupa siklus-siklus pembelajaran yang dilakukan dalam proses belajar mengajar di kelas. Dalam penelitian ini, pembelajaran dilakukan dalam dua siklus sebagaimana paparan berikut ini :

\section{Siklus Pertama (pertemuan ke lima dan enam)}

Siklus pertama terdiri dari empat tahap, yakni perencanaan, pelaksanaan, observasi dan refleksi serta replaining, seperti berikut :

a. Perencanaan (Planning)

1) Peneliti melakukan analisis kurikulum untuk mengetahui kompetensi dasar yang akan disampaikan kepada peserta didik 
dengan menggunakan model pembelajaran Team Games Tournament (TGT) melalui permainan monopoli

2) Membuat rencana pembelajaran kooperatif tipe TGT melalui permainan monopoli

3) Membuat Lembar Kerja Siswa

4) Membuat instrumen yang digunakan dalam siklus PTK

5) Menyusun alat evaluasi pembelajaran

b. Pelaksanaan (Acting)

Pada saat awal siklus pertama pelaksanaan belum sesuai dengan rencana. Hal ini disebabkan:

1) Sebagian kelompok belum terbiasa dengan kondisi belajar TGT melalui permainan monopoli

2) Pengelolan waktu belum bisa maksimal, karena terlena dengan permainan monopoli

3) Langkah kerja kurang diuraikan di Lembar Kerja Siswa (LKS)

Untuk mengatasi masalah di atas, dilakukan upaya sebagai berikut :

a. Guru dengan intensif memberi pengertian kepada peserta didik kondisi dalam kelompok, kerjasama kelompok, keikutsertaan siswa dalam kelompok

b. Lebih membatasi pertanyaan pada kelompok yang ingin membeli petak pada monopoli, sehingga lebih dipertajam ke pencapaian tujuan pembelajaran dan indikator

c. Memperbaiki bentuk Lembar Kerja siswa agar lebih dipahami peserta didik, sehingga peserta didik runut dalam melaksanakan langkah-langkah kegiatan praktek

Pada akhir siklus pertama dari hasil pengamatan observer dapat disimpulkan:

a. Peserta didik mulai terbiasa dengan model pembelajaran TGT melalui permainan monopoli

b. Peserta didik mampu menyimpulkan bahwa pembelajaran TGT memiliki langkahlangkah tertentu

c. Observasi dan evaluasi (Observation and Evaluation)

1) Hasil observasi aktivitas siswa dalam Pembelajaran selama kegiatan praktek pada siklus pertama dapat dilihat bahwa ada empat orang yang memiliki predikat baik, lima belas orang memiliki predikat sangat baik (dapat dilihat pada lampiran). Memiliki rata-rata sebesar $88,81 \%$, dengan skor tertinggi $100 \%$ dan skor terendah $70 \%$.

2) Hasil observasi aktivitas guru dalam Pembelajaran selama kegiatan praktek pada siklus pertama sudah mempunyai klasifikasi amat baik dengan kategori A. Skor perolehannya adalah 46, sedangkan skor ideal adalah 48.

3) Hasil Evaluasi untuk penguasaan materi praktek, juga sudah menunjukkan hampir mendekati ideal. Karena skor yang didapat adalah 20 atau 83,33\% sedangkan skor idealnya adalah 24 .

4) Untuk hasil belajar pada siklus pertama, peserta didik masih rendah nilainya.Penilaian Hasil belajar didapat dari hasil post test. Hanya memiliki rata-rata 77,47 , dengan ketuntasan klasikal sebesar 52,63\%. Jumlah peserta didik yang sudah berkompeten hanya 10 orang dari 19 orang peserta didik.Berikut adalah grafik Hasil belajar Praktek Teknik Konversi Bahan pada siklus I.

\section{Grafik Hasil Post Test Siklus I}

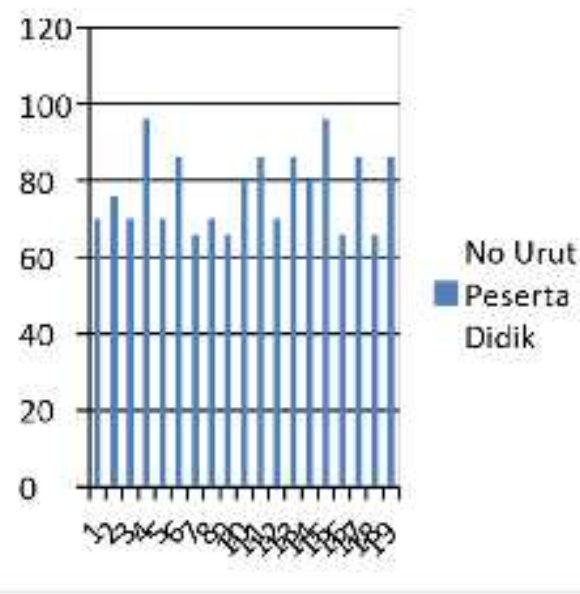

d. Refleksi dan Perencanaan Ulang (Reflecting and Replanning)

Adapun keberhasilan dan kegagalan yang terjadi pada siklus pertama adalah sebagai berikut : 
1) Guru masih belum sempat menyampaikan indikator dan tujuan pembelajaran, sehingga peserta didik belum mengetahui tujuan dari pelaksanaan praktek.

2) Penilaian akhir belajar harus ada bukti berupa soal dan jawaban

3) Guru belum bisa mengaitkan atau merefleksi, apa manfaat dari pelaksanaan praktek pada kehidupan sehari-hari

4) Peserta didik terlihat antusias dan berminat mengikuti permainan monopoli, hingga selesai, sehingga kesan bengong dan kabur pada saat praktek mulai terkikis

5) Perlunya guru pendamping atau laboran, sehingga ada yang membantu guru pada saat praktikum berlangsung

6) Masih terkesan guru yang banyak bertanya, peserta didik kurang aktif bertanya, hanya aktif menjawab

7) Hasil post test pada siklus pertama sudah agak bagus. Hal ini ditunjukkan dengan rata-rata yang dicapai sebesar 77,47

8) Masih ada kelompok yang tidak sesuai prosedur melakukan pembelajaran praktek, dikarenakan kurang sempurnanya Lembar Kerja Siswa (LKS).

Untuk memperbaiki kelemahan dan mempertahankan keberhasilan yang telah dicapai pada siklus pertama, maka pada pelaksanaan siklus kedua dapat dibuat perencanaan sebagai berikut:

a. Memberikan motivasi kepada kelompok agar lebih efektif lagi dalam pembelajaran

b. Lebih intensif membimbing kelompok yang mengalami kesulitan dalam melakukan kegiatan praktek

c. Lebih banyak memberikan reward atau penghargaan dan pengakuan kepada kelompok yang berhasil memperoleh skor tertinggi

\section{Siklus kedua (Pertemuan ketujuh dan kedelapan)}

a. Perencanaan (Planning)

Planning pada siklus kedua berdasarkan replanning siklus pertama, yaitu:
1) Memberikan motivasi kepada kelompok agar lebih aktif lagi dalam melakukan kegiatan praktek

2) Lebih intensif lagi membimbing kelompok yang mengalami kesulitan

3) Memberikan pengakuan dan penghargaan (reward)

4) Membuat perangkat pembelajaran kooperatif tipe TGT melalui permainan monopoli yang lebih baik lagi

b. Pelaksanaan (Acting)

1) Suasana pembelajaran sudah lebih mengarah kepada pembelajaran kooperatif tipe TGT melalui permainan monopoli. Tugas yang diberikan guru kepada kelompok dengan menggunakan Lembar Kerja Siswa (LKS) mampu dikerjakan lebih baik lagi dengan waktu yang juga sudah terkontrol dengan baik. Peserta didik dalam satu kelompok menunjukkan saling membantu untuk menguasai materi pelajaran yang telah diberikan melalui diskusi dengan sesama kelompoknya atau tanya jawab dengan guru.

2) Peserta didik lebih antusias mengikuti proses belajar mengajar pada kegiatan praktek

3) Suasana pembelajaran yang efektif dan menyenangkan sudah lebih tercipta

4) Observasi dan Evaluasi (Observation and Evaluation)

5) Hasil observasi aktivitas siswa dalam Pembelajaran selama kegiatan praktek pada siklus kedua sudah menunjukkan perubahan yang signifikan dari siklus pertama. Hal ini dapat dilihat dari sebanyak 19 peserta didik menunjukkan predikat "sangat baik" dengan skor perolehan terendah $75 \%$ dan skor tertinggi $100 \%$

6) Hasil observasi aktivitas guru dalam Pembelajaran selama kegiatan praktek pada siklus kedua sudah mempunyai klasifikasi amat baik dengan kategori A. Skor perolehannya adalah 47, sedangkan skor ideal adalah 48.

7) Hasil Evaluasi untuk penguasaan materi praktek, juga sudah menunjukkan hampir mendekati ideal. Karena skor yang didapat 
adalah 23 atau 95,83\% sedangkan skor idealnya adalah 24 .

8) Untuk hasil belajar pada siklus kedua, ratarata yang dicapai peserta didik mengalami peningkatan yang cukup berarti, yakni 83,37 , sedangkan sebelumnya hanya 77,47 , dengan ketuntasan klasikal sebesar 84,21\%. Jumlah peserta didik yang sudah berkompeten meningkat menjadi 16 orang dari 19 orang peserta didik. Berikut adalah grafik Hasil belajar Praktek Teknik Konversi Bahan pada siklus II.

\section{Grafik Hasil Post Test Siklus II}

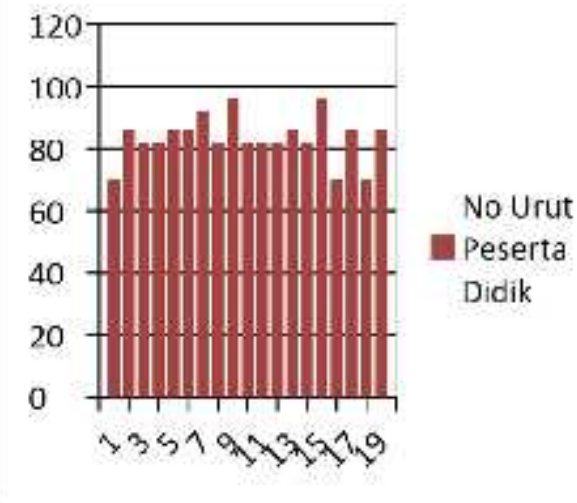

c. Refleksi (Reflecting)

Adapun keberhasilan yang diperoleh selama siklus kedua ini adalah sebagai berikut:

1) Aktivitas peserta didik dalam pembelajaran praktik sudah mengarah ke pembelajaran kooperatif secara lebih baik. Peserta didik mampu membangun kerjasama dalam kelompok untuk memahami tugas yang diberikan guru. Peserta didik mulai mampu berpartisipasi dalam kegiatan dan tepat waktu dalam melaksanakannya. Hal ini ditunjukkan dengan adanya peningkatan aktivitas peserta didik dari 88,81\% meningkat hingga 94,03\%.

2) Peserta didik mulai dapat menganalisa kesalahan yang terjadi dalam hasil praktek.

3) Meningkatnya aktivitas peserta didik dalam pembelajaran praktek didukung pula dengan meningkatnya aktivitas guru dalam mempertahankan dan meningkatkan suasana pembelajaran, dengan cara lebih intensif membimbing peserta didik, terutama peserta didik yang mengalami kesulitan dalam menganalisa langkah prosedur praktek. Hal ini dapat dilihat dari peningkatan aktivitas guru dari $95,83 \%$ menjadi $97,92 \%$ pada siklus kedua

4) Meningkatnya rata-rata hasil belajar praktek peserta didik, yang di siklus pertama hanya 77,47 menjadi 83,37 pada siklus kedua.

\section{SIMPULAN}

Berdasarkan hasil Penelitian Tindakan Kelas dapat disimpulkan sebagai berikut:

1. Dari hasil observasi memperlihatkan bahwa terjadi peningkatan aktivitas peserta didik yang pada siklus I hanya rata-rata $88,81 \%$ menjadi $94,03 \%$ pada siklus II

2. Penguasaan terhadap materi pembelajaran praktek menunjukkan peningkatan. Hal ini dapat ditunjukkan dengan rata-rata hasil post test pada siklus pertama sebesar 77,47 menjadi 83,37 pada siklus kedua

3. Dengan menggunakan permainan monopoli, peserta didik lebih interaktif dan pembelajaran praktek yang awalnya banyak yang ingin kabur menjadi lebih menyenangkan

\section{DAFTAR PUSTAKA}

Arikunto, S. 2010. Penelitian Tindakan untuk Guru, Kepala Sekolah dan Pengawas. Jogjakarta. Aditya Media

Anonymous, 2011. Pembelajaran Praktek. www.fajaralayyubi.wordpress.com. Diakses tanggal 3 Oktober 2013

Anonymous, 2013

Monopoly Game.mainmonopoly.blogspot.com. Diakses Tanggal 08 September 2010

Anonymous, 2013. Model Pembelajaran TGT. http://ekocin.wordpress.com. Diakses Tanggal 17 Juni 2011

Anonymous, 2013. Monopoli (Permainan). id.wikipedia.org. Diakses Tanggal 10 Oktober 2013

Sugiyono, 2009. Metode Penelitian. Bandung. Alfabeta 
Trianto, 2007. Model-model Pembelajaran

Terpadu dalam Teori dan Praktek. Jakarta.

Prestasi Pustaka Publisher 